\title{
PHALENA STRIX.
}

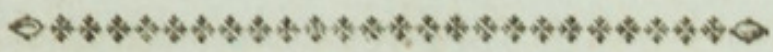

CHARACTER GENERICUS.

Antenno setacex, a basi ad apicem sensim attenuatæ.

Alé (sedentis) sæpius deflexæ. (Volatu nocturno.)

Lin. Syst. Nat.p. 808.

Character SPECificus, Ëc.

PHAL FNA ALBIDA, alis concoloribus fusco nigroque reticulatis nebulosisque.

PHAL FNA STRIX? P. alis concoloribus albo nigroque reticulatis nebulosisque? Lin. Syst. Nat. Gmel. p. 2529. Cram. pap. vol. 2. t. 145.f. A.

Insulas Indicus, præcipue Javam et Amboynam incolit Phalæna Strix, magnitudine vera in tabula depicta. 



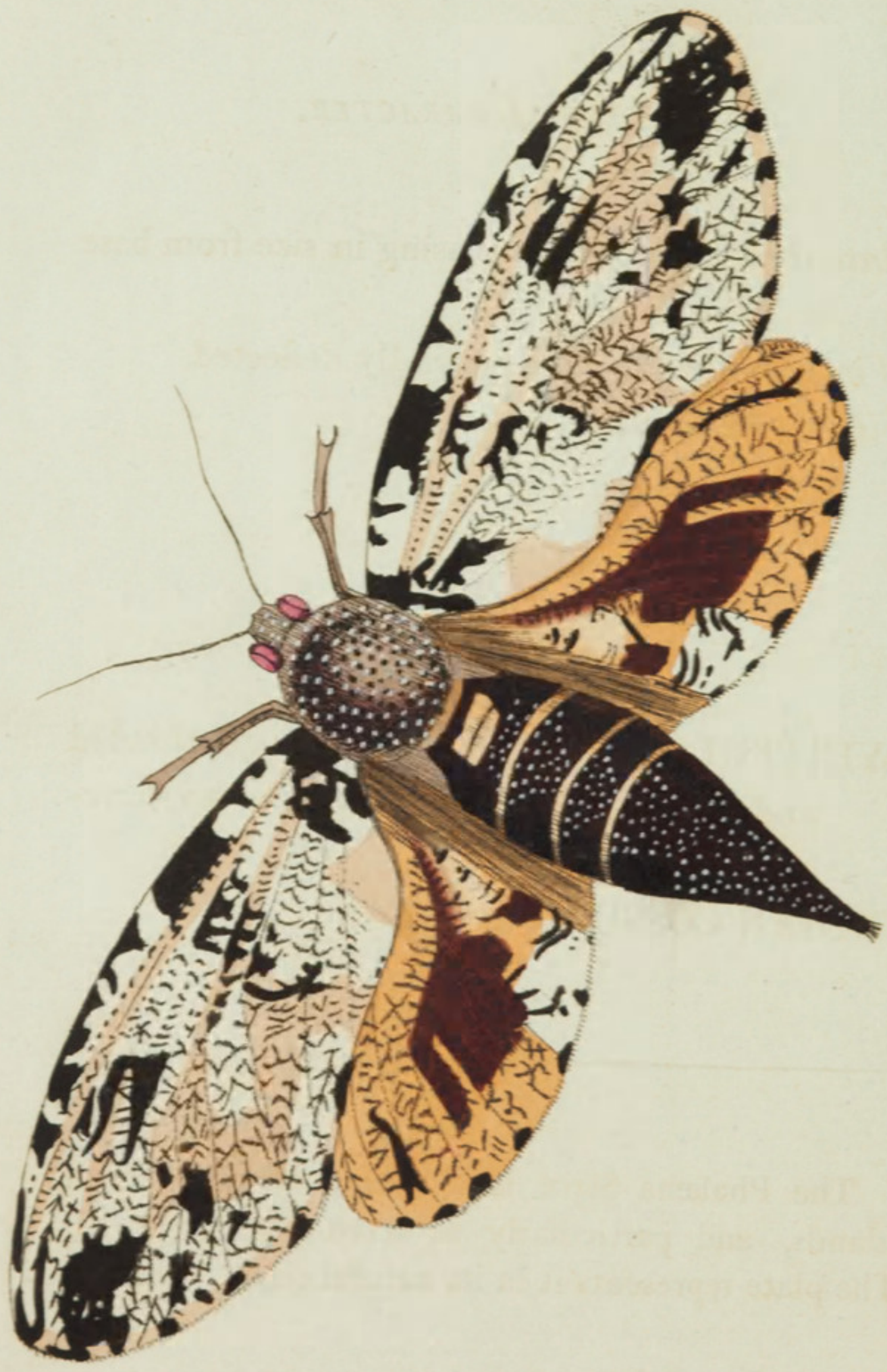




\section{STRIX.}

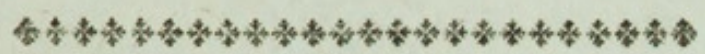

GENERIC CHARACTER.

Antenna setaceous, decreasing in size from base to point.

Wings (when at rest) génerally deflected. Flight nocturnal.

SPECIFIC CHARACTER, $\S^{2}$.

WHITISH MOTH, with the wings clouded and reticulated by black and brown yariegations.

INDIAN COSSUS or Owl-Moth.

The Phalæna Strix is a native of the Indian islands, and particularly of Java and Amboina. The plate represents it in its natural size. 


\section{$2 \mathrm{BHL}$ Biodiversity Heritage Library}

Shaw, George. 1804. "Strix, Phalæna strix [PI. 618]." The Naturalist's Miscellany 15(CLXXVII), https://doi.org/10.5962/p.311059.

View This Item Online: https://www.biodiversitylibrary.org/item/280634

DOI: https://doi.org/10.5962/p.311059

Permalink: https://www.biodiversitylibrary.org/partpdf/311059

\section{Holding Institution}

Museums Victoria

\section{Sponsored by}

Atlas of Living Australia

\section{Copyright \& Reuse}

Copyright Status: Public domain. The BHL considers that this work is no longer under copyright protection.

This document was created from content at the Biodiversity Heritage Library, the world's largest open access digital library for biodiversity literature and archives. Visit BHL at https://www.biodiversitylibrary.org. 